\title{
Large-group psychodynamics and massive violence
}

\author{
Psicodinâmica da violência de grandes \\ grupos e da violência de massas
}

\begin{abstract}
Beginning with Freud, psychoanalytic theories concerning large groups have mainly focused on individuals' perceptions of what their large groups psychologically mean to them. This chapter examines some aspects of large-group psychology in its own right and studies psychodynamics of ethnic, national, religious or ideological groups, the membership of which originates in childhood. I will compare the mourning process in individuals with the mourning process in large groups to illustrate why we need to study largegroup psychology as a subject in itself. As part of this discussion I will also describe signs and symptoms of large-group regression. When there is a threat against a large-group's identity, massive violence may be initiated and this violence in turn, has an obvious impact on public health.
\end{abstract}

Key words Large-group identity, Large-group regression, Wars, Mourning, Chosen trauma
Resumo A partir de Freud, as teorias psicanalíticas a respeito de grandes grupos focalizam principalmente as percepções e os significados que os individuos psicologicamente atribuem a eles. Este texto analisa alguns aspectos sobre a psicologia dos grandes grupos e sua psicodinâmica interna e específica. Toma como referência grupos étnicos, nacionais, religiosos e ideológicos cujo pertencimento dos sujeitos iniciou-se na infância. Faz-se uma comparação entre o processo de luto em indivíduos e o processo de luto em grandes grupos para ilustrar por que é necessário investir no conhecimento da psicologia destes últimos, como um objeto específico. Descreve ainda sinais e sintomas de regressão em grandes grupos. Quando há ameaça à identidade coletiva pode ocorrer um processo de violencia de massas que obviamente influencia na sua saúde coletiva.

Palavras-chave Identidade de grandes grupos, Regressão de grandes grupos, Guerras, Luto, "Traumas selecionados"
1 University of Virginia. 1909 Stillhouse Road, Charlottesville, VA 22901. vdv@virginia.edu 
Since I am a psychoanalyst, I naturally approach the study of large-group psychodynamics and violence primary from a psychoanalytic angle. In 1932 Albert Einstein wrote a letter to the father of psychoanalysis, Sigmund Freud, asking if this new science could offer insights that might deliver humankind from the menace of war. In his response to Einstein, Freud 1 expressed little hope for an end to war and violence, or the role of psychoanalysis in changing human behavior beyond the individual level. Even though some analysts such as Jacob Arlow 2 have found indications of cautious optimism in some of Freud's writings, Freud's general pessimism was mirrored by many of his followers. This, I think, has played a key role in limiting the contributions psychoanalysis has made to international relations in general and in finding more peaceful solutions for conflicts between enemy groups in particular.

Another factor that has played a role in limiting such psychoanalytic contributions, I believe, was the impact of the Holocaust on psychoanalytic practice ${ }^{3}$. Let me explain: in his early efforts to develop psychoanalytic theories, Freud gave up the idea that the sexual seduction of children came from the external world, and instead focused on the stimuli that comes from the child's own wishes and fantasies for formation psychopathology. Since early psychoanalysts followed this tradition, classical psychoanalysis accepted this de-emphasis on actual seduction coming from the external world when considering the developing child's psyche and generalized it to include de-emphasis on the role of traumatic external events. This de-emphasis included traumatic international events as they impact the mental health of individuals affected by them. The Holocaust is a prime example. For a long time, psychological studies of the Holocaust were too painful to be carried out, and the whole topic of its psychological impact on those who were affected directly and on the human psyche in general was avoided. (Despite of some studies on this topic, in general, a "denial" of the psychological plight of Holocaust survivors strangely persisted for decades after the World War II - a defense that, astonishingly, extended even to Israel. In a November 2, 1995 story, an Israeli television station reported that even the Jewish state had long neglected the trauma undergone by Holocaust survivors. After their arrival in 1940s, survivors had been immediately treated for depression and other mental disorders in psychiatric hospitals. Incredibly, however, many of these patients' official files did not even mention that they were Holocaust victims.)

Harold Blum's ${ }^{4}$ description of a Jewish patient who came to him for re-analysis illustrates the extent to which mutual resistances may prevail when both the analyst and the analysand belong to the same large group that has been massively traumatized by an external historical event. Blum's ${ }^{4}$ patient's first analyst, who was also Jewish, failed to "hear" their large group's shared trauma at the hands of the Nazis in his analysand's material. As a consequence, mutually sanctioned silence and denial pervaded the entire analytic experience, leaving unanalyzed residues of the Holocaust-related issues in the analysand's symptoms.

We can wonder how many Jewish analysts after World War II were like Blum's patient's former analyst and how many of them, without being aware of it, influenced the application of psychoanalytic treatment in a way that tended to ignore Holocaust-related external reality. I suggest that some of them who were very influential in the field of psychoanalysis, both in the US and elsewhere, exaggerated their bias in favor of a theoretical position called "classical analysis" that focused only on the analysand's internal wishes and fantasies. We now know that in post-World War II Germany as well, there has been both German and German-Jewish analyst-supported (unconscious) resistance to exploring the intertwining of internal and external wars and the influence of Holocaust-related issues on analysands' psyches (Jokl5; Grubrich-Simitis6; Eckstaedt7; StreeckFischer8; and Volkan, Ast and Greer $\left.{ }^{9}\right)$.

Since Freud, many authors who are not themselves practicing psychoanalysts have referred to psychoanalysis in their attempt to understand world affairs and large-group psychology in general. They have often referred to Freud's 10 , 11, 12, 13 writings such as Totem and Taboo, Group Psychology and the Analysis of the Ego, The Future of an Illusion, Civilization and its Discontents, and his correspondence with Einstein mentioned above. The main problem with their approach, as Ivan Hendrick 14 noticed long ago, is that because of it, psychoanalysis is misused by intellectuals, who argue its validity as if it were a philosophy, an ethical system, a set of theories; such discussion [...] seems alien and unproductive to the analyst himself, whose primary convictions originate in what his patients have told him. This approach by these authors 
usually overlooked two important considerations. First, psychoanalytic theories that systematize new findings in the field have been expanded enormously in the decades since Freud's first pioneer work. To be sure, some authors who are not practicing psychoanalysts now refer to new psychoanalytic theoreticians, such as Jacques Lacan, when writing about large-group psychology. In general, however, these authors also utilize the new psychoanalytic theories as if they were a set of philosophical considerations.

Second, observations afforded by clinical psychoanalytic practice have much more to offer the study of world affairs, ethnic identity, political leader-followers interactions, the eruption of massive violence and its influence on public health. Working with children in psychoanalytic therapy or analyzing borderline or narcissistic adults, in my mind, informs us more about large-group psychology than does studying metapsychology or psychoanalytic theories of the mind. Often international relationships are dominated by the utilization of shared primitive defense mechanisms such as introjection, projection, splitting, and denial. Clinical work with children, borderline and narcissistic patients teach us a great deal about such mechanisms.

Meanwhile, practicing psychoanalysts, with some exceptions, have basically tended to treat their patients without much interest in or attention paid to political or diplomatic issues and the enormous public health problems that are found in massively traumatized societies. When writing about such issues, they usually apply theories of individual psychology to large-group processes without taking into consideration that once they begin, large-group processes take on their own specific directions and appear as new political, social or ideological movements. Recently however, especially since September 11, 2001, practicing psychoanalysts have shown more interest in largegroup psychology.

My findings on large-group psychology come from actual fieldwork in various troubled spots of the world. In 1977, then-Egyptian president Anwar el-Sadat stunned the political world by visiting Israel. When he addressed the Israeli Knesset he spoke about a psychological wall between Arabs and Israelis and stated that psychological barriers constitute 70 percent of all problems existing between the Arabs and the Israelis. With the blessings of the Egyptian,
Israeli and American governments, the American Psychiatric Association's (APA's) Committee on Psychiatry and Foreign Affairs followed up on Sadat's statements by bringing together influential Israelis, Egyptians and later Palestinians for a series of unofficial negotiations that took place between 1979 and 1986. My membership in this committee initiated my study of large-group psychology, enemy relationships, and interactions between political leaders and their followers, and I began contemplating strategies to tame aggression between enemy groups.

This six-year study of the Arab-Israeli conflict as seen through a psychological lens was also the opportunity that provided the beginnings of my examination of the psychology of large groups and societies in its own right. Later I observed other "enemy" representatives - such as Russians and Estonians, Georgians and South Ossetians, Serbs and Croats or Turks and Greeks - in various years-long unofficial negotiation series. I also interviewed traumatized people in refugee camps where "we-ness" becomes palpable. Furthermore, I spent time with political leaders such as the former US president Jimmy Carter, former Soviet leader Mikhail Gorbachev, the late Yasser Arafat, the present Estonian president Arnold Rüütel, and Northern Cyprus president Rauf Denktas as and observed aspects of leader-followers psychology through these leaders' verbalized thought processes and actions. Eventually, I was able to define the concept of "large-group identity": a sense of sameness shared by thousands or millions of people. It is this sense of sameness which explains what people mean when they say, "We are Finnish," "We are Arabs," "We are Jews," or "We are communists"15, 16, 17, 18, 19.

\section{Large-group identity}

Because of their clinical interests, psychoanalysts have focused more on small groups and the psychodynamics involved when seven to fifteen individuals gather for a series of meetings. Wilfred Bion's ${ }^{20}$ work is among the best known of such studies. A "small group" with a definite leader, a structured task, and an awareness of time evolves as a "work group" and performs its task with an adaptation to reality. Bion describes how, when such a group's security is threatened or when it is not given a realistic and structured task, it begins to function according 
to certain "basic assumptions," which are very familiar to psychoanalysts.

In the psychoanalytic literature the term "large group" often refers to 30 to 150 members who meet in order to deal with a given issue. When the task given to such a "large group" is by design unstructured and vague, the "large group" regresses. At this time, observers notice increased anxiety, chaos, and panic among its members21, 22, 23, 24. In order to escape the panicky atmosphere that envelopes them, regressed "large groups" exhibit narcissistic or paranoid characteristics and reorganize themselves by sharing and utilizing primitive mental mechanisms.

Otto Kernberg also refers to groups composed of 30 to 150 individuals as "large groups." He uses the term "crowds" when he refers to spectators at a big sports event or large theatrical performance. He also mentions disorganization in crowds after natural disasters and then speaks of "mass movements" and "societal and cultural processes." He primarily illustrates the emergence of aggression in "small groups," "crowds" and "societies" when regression and disorganization sets in.

In this chapter I refer to tens, hundreds of thousands, or millions of individuals - most of whom will never meet during their lifetimes who belong to a large group from childhood on. I use the term large-group identity (i.e. an ethnic identity) to refer to a shared permanent sense of sameness.

The psychodynamics of ethnic, national, religious or ideological large groups are different from the psychodynamics of "small groups," "large groups" (composed of 30 or 150 individuals), or "crowds." For example, a "crowd" in a football stadium becomes a group and remains so just before, during, and perhaps soon after the sports event. On the other hand, let us consider an ethnic or religious large group, like Greeks or Catholics. The membership in these large groups begins in childhood. Elsewhere I illustrate how each member's core personal identity is intertwined with their large-group identity $16,19$.

When I think of the classical Freudian theory of large groups, I visualize people arranged around a gigantic maypole, which represents the group leader. Individuals in the large group dance around the pole/leader, identifying with each other and idealizing the leader. I have expanded this maypole metaphor by imagining a canvas extending from the pole out over the people, forming a huge tent. This canvas represents the large-group identity. I have come to the conclusion that essential large-group psychodynamics center around maintaining the integrity of the large-group identity, and leaderfollower interactions are just one element of this effort.

Imagine thousands or millions of persons living under this huge tent. They may get together in subgroups - they may be poor or rich or women or men and they may belong to certain clans or professional organizations - but all of them are under one huge tent. The pole of the tent is the political leadership. From an individual psychology point of view, the pole may represent an oedipal father; from a largegroup psychology point of view, the pole's task is to keep the tent's canvas erect (to maintain and protect the large-group identity). Everyone under the tent's canvas wears an individual garment (personal identity), but everyone under the tent also shares the tent canvas as a second garment. Elsewhere I have identified seven threats that, when they are woven together, produce the cloth - the canvas of the largegroup tent - ranging from shared identifications to "chosen traumas"17, 19, a term I will explain later in this chapter.

In our routine lives we are not keenly aware of our shared second garment, just as we are not usually aware of our constant breathing. If we develop pneumonia or if we are in a burning building, we quickly notice each breath we take. Likewise, if our huge tent's canvas shakes or parts of it are torn apart, we become obsessed with our second garment, and our individual identity becomes secondary. (Before going any further I must explain that here I am speaking of general large-group processes, leaving out certain people such as dissenters). We become preoccupied with the large-group identity and will do anything to stabilize, repair, maintain and protect it, and when we do, we are willing to tolerate extreme sadism or masochism if we think that what we are doing will help to maintain and protect our largegroup identity. In the long run, such behavior is inevitably reflected in public health issues.

\section{Large-group psychodynamics}

Since large groups are made up of individuals, it stands to reason that large-group processes reflect individual psychology. But a large group 
is not a living organism that has one brain, so once a large-group process starts within the society, it establishes a life of its own. To illustrate this I will compare the process of mourning in an individual and in a large group.

Psychoanalysts, psychiatrists and other mental health professionals know a great deal about the individualized process of mourning. Mourning is an obligatory human psychobiological response to a meaningful loss. When a loved one dies, the mourner has to go through predictable and definable phases until the mourning process comes to a practical end $25,26$. Finnish psychoanalyst Veikko Tähkä27, along with others going all the way back to Sigmund Freud 29 himself, contributed greatly to our understanding of the individual mourning process during which the mourner internally reviews his or her experiences with the lost person and slowly lets this person be psychologically "buried." If everything goes in a routine fashion, the mourner also identifies with aspects and functions the dead person possessed when still living, and keeps the dead person "alive" within the mourner's psyche. This process takes a few years. Sometimes the individual mourning processes can be "infected" due to various causes, and we can predict what may happen after such "infections."

Large groups also mourn. Since a large group is not one living organism, the psychodynamics of its mourning over the loss of loved ones, lands, and prestige after a war or war-like situation will manifest as societal processes. For example, after a major shared trauma and loss at the hand of enemies, a political ideology of irredentism - a shared sense of entitlement to recover what had been lost - may emerge that reflects a complication in large-group mourning and an attempt both to deny losses and to recover them. What Greeks call the Megali Idea (Great Idea) is this kind of political ideology. Such political ideologies may last for centuries and may disappear and reappear when historical circumstances change ${ }^{29}$.

The last time we very clearly witnessed the reappearance of a political ideology of entitlement was after the collapse of Yugoslavia. When the huge Yugoslav tent was gone the Serbs, the Croats, the Bosniaks and others became preoccupied with establishing themselves under their specific smaller tents. When a large group asks, "Who are we now?" it becomes preoccupied with repairing, protecting and maintaining the canvas of its tent. In order to hold on to the large-group identity, it tries to illuminate specific symbols woven into the fabric of its tent's canvas. When ethnic, nationalistic, religious or ideological identity markers are illuminated, doing so reassures the society that their largegroup identity still exists. I named one of these significant markers a chosen trauma.

A chosen trauma is the shared mental representation of an event in a large group's history in which the group suffered a catastrophic loss, humiliation, and helplessness at the hands of enemies. When members of a victim group are unable to mourn such losses and reverse their humiliation and helplessness, they pass on to their offspring the images of their injured selves and psychological tasks that need to be completed. This process is known as the "transgenerational transmission of trauma." (For a review and an examination of this concept see: Volkan, Ast and Greer ${ }^{9}$ ). All such images and tasks contain references to the same historical event, and as decades pass, the mental representation of such an event links all the individuals in the large group. Thus, the mental representation of the event emerges as a significant largegroup identity marker. A chosen trauma reflects the "infection" of a large-group's mourning process, and its reactivation serves to link the members of a large group. Such reactivation can be used by the political leadership to promote new massive societal movements, some of them deadly and malignant.

Political leaders may initiate the reactivation of chosen traumas in order to fuel entitlement ideologies. The story of how Slobodan Milosevic allowed and supported the re-appearance of the Serbian chosen trauma - the mental representation of the June 28, 1389 Battle of Kosovo - is well documented ${ }^{16}$. According to the myth that developed among the Serbs some 70 years after the Battle of Kosovo, the event and the Serbian characters of this battle - especially the Serbian leader Prince Lazar who was killed during the battle - mingled with elements and characters of Christianity. As decades passed, Prince Lazar became associated with Jesus Christ, and icons showing Lazar's representation in fact decorated many Serbian churches throughout the six centuries following the battle. Even during the communist period when the government discouraged hero worship, Serbs were able to drink (introject) a popular red wine called "Prince Lazar."

As the six-hundredth anniversary of the Battle of Kosovo approached in 1989, with the 
permission and encouragement of Milosevic, Lazar's 600-year-old remains, which had been kept north of Belgrade, were placed in a coffin and taken over the course of the year to almost every Serb village and town, where they were received by huge crowds of mourners dressed in black. Again and again during this long journey, Lazar's remains were symbolically buried and reincarnated, until they were buried for good at the original battleground in Kosovo on June 28, 1989. On this day, the six-hundredth anniversary of the Battle of Kosovo, a helicopter brought Milosevic to the burial ground where a huge monument made of red stone symbolizing blood had been built. In the mythology, Prince Lazar had chosen the Kingdom of Heaven over the Kingdom of earth. By design, Milosevic descended from a helicopter, representing Prince Lazar coming to earth to find a new Kingdom, a Greater Serbia.

Thus Milosevic and his associates, by activating the mental representations of Lazar and the Battle of Kosovo, along with the peak emotions they generated, were able to create a yearlong "time collapse": The perceptions, feelings, and expectations concerning a past hero and event were collapsed into the perceptions, feelings, and expectations about at a current "enemy," thus magnifying its threat. Milosevic and his associates first encouraged a shared sense of victimization followed by a shared sense of entitlement for revenge. This led to genocidal acts in Europe at the end of the 20th century. In early June 2005, new tapes showing violent murders in the name of large-group identity shook the Serbian citizenry - as well as the rest of us.

Imagine that a serial killer such as Jack the Ripper is murdering his victims by strangling them with a red scarf. Also imagine that this serial killer is caught, tried and put away. What happens to his murder weapon, the red scarf? It stays in a dusty box in the basement of a court or police building as evidence used during the trial. In short, in the future no one else will use this scarf as a "tool" for murdering people.

Let us go back to Milosevic. At the present time he is on trial because the United Nations considers him responsible for mass murder, among other things. What was Milosevic's "red scarf" and what will happen to it? As I described above, one of Milosevic's prominent "tools" for inciting extreme violence was his reactivation (with the help of some Serbian academicians and people from the Serbian Church) of shared symbols of the Serbian large-group identity: mental representations of loss, humiliation, the Battle of Kosovo, and the Serbian leader Prince Lazar who was killed during this battle.

Now let us imagine that Milosevic is found guilty and is put away, but his "red scarf" is not put away in a basement. Since this "red scarf" belongs to the large group and not to one lone individual, it is possible to use it again in the future. We know this because Milosevic is not the first person to inflame the mental representations of the Battle of Kosovo and Prince Lazar. On June 28, 1914, during an anniversary of the Battle of Kosovo, a Serb named Gavrilo Prencip assassinated Archduke Francis Ferdinand of Austria-Hungary (Austria-Hungary had replaced the Ottoman Empire as the "oppressor" of the Serbs) and his pregnant wife in Sarajevo, thereby beginning World War I.

The political and legal systems have no effective methods to deal with a "tool" that can be used for massive destruction when it belongs to a large group rather than just the man or woman who makes use of it. It can be better understood by the application of psychological insights that illuminate large-group processes in their own right than by logical realpolitik conceptualizations. Who is going to examine "red scarves" that are the property of large groups? I hold that psychoanalysts and others who study human nature are best equipped to do so if they are willing to venture beyond their offices, conduct field work, and collaborate with scholars and practitioners from other disciplines in an effort to understand collective human issues such as politics, diplomacy, wars, terrorism and the reflection of these things in the realm of public health.

\section{Large-group regression}

When a large-group identity is threatened and this can be by any variety of things such as the group's enemies - the ethnic, national, religious or ideological large group regresses. (Although I have found 20 signs and symptoms of this kind of regression 17 , I must borrow the term "regression" from individual psychology because we do not have a word that stands only for large-group regression.) When a large group regresses it becomes involved in certain societal processes that serve to maintain, protect and repair the large-group identity. Since large groups as I described them here have their own specific characteristics that are 
built upon their own centuries-old continua and shared mental representations of history and myth, the examination of signs and symptoms of their regression should also include shared psychodynamics that are specific to each group. We need therefore to go beyond a general description of the emergence of aggression in large groups, when they regress, and their shared paranoid or narcissistic sentiments, and refer to actual manifestations of regression within each specific large group.

Some major signs of large-group regression, such as rallying around the leader - as occurred in the USA immediately following the September 11, 2001 terrorist attacks - have been known since Freud. When Freud ${ }^{11}$ wrote about this phenomenon he did not say he was referring to regressed groups, and it was Robert Waelder ${ }^{30}$ who brought to our attention that it was in fact regressed groups that Freud was describing. Sometimes the members of a large group continue to rally around a leader for decades and they remain "regressed' in order to modify existing characteristics of their large-group identity. In this situation what we observe is similar to an individual's regressing in the service of progression and creativity. After the collapse of the Ottoman Empire and the establishment of modern Turkey in 1923 under the leadership of Kemal Atatürk, the Turkish people (in general) continued to rally around Atatürk until his death in $1938^{29}$. This was the main factor that supported modern Turkey's cultural revolution and the modification of characteristics of the Turks' largegroup identity.

Often however, a large group regression does not serve a positive outcome. For example, in certain totalitarian regimes, people rally around the leader in order to feel personally secure rather than to be punished by the authorities for disobeying the "rules" of the regime. Without being aware of it, they internalize what Michael Sebek 31 called "totalitarian objects," and blindly follow their leader by giving up many aspects of their individuality.

When a large group is in a regressed state, the personality and the internal world of the political leader assumes great importance concerning the manipulation (the "good" or the "bad") of what already exists within the largegroup psychology. Therefore, the personality organization of Milosevic, which I describe elsewhere16, was a crucial factor in what happened in the former Yugoslavia, and demon- strates how political leaders such as Milosevic will bring the large group's "red scarves" out in the open and use them as tools of mass aggression.

Two types of splitting are also signs of large-group regression. First, a splitting between "us" and "them" (the enemy outside the regressed large group) becomes pronounced and the "other" becomes a target for dehumanization. Second, following the initial rallying around the leader, a severe split may occur within the society itself. This happens especially when the leader cannot differentiate between where real danger ends and fantasized danger begins, but instead leads the group to resemble the enemy group in certain areas, such as the curtailing of individual rights. Without this differentiation the group cannot maintain hope and cannot tame shared aggression. Just a few years after September 11, 2001 we notice such a split in the USA. There are various reasons for this, but I believe that this also reflects the regressed state of America after the massive tragedy, as well as the American leadership's failure to separate "realistic" dangers from "fantasized" dangers and its inability to help tame the population's shared anxiety.

A regression within the large group stimulates the population to share primitive mental mechanisms when dealing with the external world. I am referring to massive introjections (such as the population's "eating up" political propaganda without making much of an effort to evaluate its validity) and projections, such as happened under the totalitarian regime of Enver Hoxha when Albanians built 7,500 bunkers throughout Albania in anticipation of an enemy attack that never occurred. Building these bunkers, which would not stand against modern weapons, was also a reflection of magical thinking, another characteristic of regressed societies. We see various types of magical thinking, such as the expansion of religious fundamentalism and the increased belief in millennialism in the US, which, at the present time, strongly influence political/societal movements there.

In a regressed society political, legal or traditional borders begin to symbolize the canvas of the large-group tent. In other words, borders become highly psychologized and people, leaders, and official organizations become preoccupied with their protection. Since there is in fact a realistic danger "out there," borders obviously need to be protected and because of this, it is 
difficult to study the psychological aspects of this preoccupation. In the USA people are now subjected to the influence of a border psychology almost daily, but because of the real (and fantasized) danger magnified by political propaganda, people may not be aware of the influence of this border psychology during their routine lives. At airports, for example, they deny the assault on individual autonomy at the security check points because of the possibility of real danger. In doing this, they subject themselves to large-group psychology, and their individual psychology that normally would cause them to rebel against the intrusion from outside is put in the background.

When a large group's tent's canvas is attacked and torn apart, "minor differences" between the enemy groups become very major issues, since minor differences are experienced as unchangeable "borders" separating one large group's identity from their enemy's identity. People therefore become preoccupied, not only with major differences between their group and the enemy group, but with minor differences between them as well.

When a large group regresses, traditional family values can be replaced by ideologies, such as happened in Nazi Germany. In some regressed large groups the role of women is reduced to giving pleasure to men (sex), providing food (symbolic milk for the society under stress) and producing children for the survival of the large-group's identity. Certain societal processes begin to remind everyone of the continuing existence of the canvas (large-group identity). Cultural customs are like designs on the canvas illustrating the uniqueness of that particular large-group identity. The group wants to "repaint" such designs on the canvas to ease shared anxiety and to show that the large-group identity still survives. But in reality, the group is helpless, angry, humiliated and suffering from complicated mourning. Thus, when such designs are "repainted," they do not exactly look like the original designs; they are now sloppy and some aspects of them are exaggerated. This may very easily lead to public health problems. One example of this can be found in what is now the Republic of Georgia. After the collapse of the Soviet Union, bloody fights took place between ethnic Georgians and ethnic South Ossetians living within the same legal/political boundaries, and in fact, South Ossetians declared their own "independent state.” Aspects of large-group regression still linger in South Ossetia as well as in Georgia: There had been a playful cultural ritual concerning brides, in which a girl would be symbolically kidnapped and married. The cultural kidnapping customs in South Ossetia have now turned into horrible societal problems in the form of some actual kidnappings and rapes of young women.

We need to study the situation of each large group from many angles in order to find specific elements in large-group processes, to understand their underlying meanings and then begin to plan psychologically informed political strategies for inducing progression within the large group or two or more groups in conflict. The next section provides a summary of a method called the Tree Model that provides such strategies and their application.

\section{The Tree Model and large-group progression}

The "tree model," which I helped to develop during the course of my 30 years or so of actual involvement with an interdisciplinary team in international relations, uses an image of the slow growth and branching of a tree to illustrate its methods. This methodology has three basic components or phases: 1) psychopolitical diagnosis of the situation, 2) psychopolitical dialogues between members of opposing groups, and 3) collaborative actions and institutions that grow out of the dialogue process. The first phase includes in-depth psychoanalytically informed interviews with a wide range of people who represent the groups involved, through which an understanding begins to emerge concerning the main aspects, including unconscious ones, that surround the situation that needs to be addressed. The psychopolitical dialogues between influential representatives of opposing large groups are conducted under the guidance of a facilitating team and take place in a series of multi-day meetings over several years. As these dialogues progress, resistances against changing the large group's "pathological" ways of protecting its identity are brought to the surface and articulated, so that fantasized threats to large-group identity can be interpreted and realistic communication can take place. In order for the newly-gained insights to have an impact on social and political policy, as well as on the populace at large, the final phase requires the collaborative development of con- 
crete actions, programs, and institutions. This methodology allows several disciplines including psychoanalysis, history and diplomacy, to collaborate to articulate and work through underlying psychological and historical aspects of existing tensions. What is learned is then operationalized so that more peaceful coexistence between the large groups can be achieved, and threats (especially the fantasized ones) to largegroup identity coming from the "other" can be tamed. This leads to a progression within the large group. (For details of the evolution and the application of the Tree Model see Volkan ${ }^{19}$ ).

The signs of a large-group progression include preserving individuality while stabilizing family, clan and professional subgroups, and having a society where individuals and professional organizations establish a capacity for compromise without damaging integrity 32 and an ability to question what is "moral." When a large group is not regressed, there is an increased emphasis on freedom of speech, an end to the devaluation of women and children, and just and functioning civil institutions, especially a fair legal system and mental hospitals with humane care ${ }^{43}$. When a large group is not in a regressed state, its members (in general) can wonder about the enemy's "psychic reality." To understand why the "other" behaved in malignant ways does not mean forgiving and forgetting past wrongs. It means performing the difficult task of "humanizing" even the most destructive perpetrators. Horrible large-scale acts are not performed by "devils," but by humans under the specific influence of large-group psychology. I hope it is clear that here I am not focusing on individuals who, due to their own individual psychology, create chaos and tragedy such as Timothy McVeigh did when he blew up the Alfred Murrah Federal Building in Oklahoma City on April, 1995. I am instead focusing on large-group psychology that leads to hurting and killing people in the name of large-group identity. By studying the "psychic reality" of the enemy as a large group, the attacked group can explore new ways of dealing with the enemy and its threat instead of responding to the enemy and the threat by acting on signs of its own regression.

\section{Becoming like the enemy}

Al Qaeda divided the world into two categories. After September 11 America did the same (again I am not speaking of individuals here, but referring to a general large-group process) and ideas such as the "clash of civilizations" or religions directly or indirectly was supported within the society. Dividing the world into a clearcut "us" and "them" is a sign of large-group regression. Responding to an enemy in a non-regressed fashion is a very difficult task. Realistic and logical actions are easily contaminated with emotions that support the human wish to do to the enemy what it did to us. I do not think that humans (as large groups) have ever entertained the idea or developed the ability to refrain from acting like their enemies once they feel threatened or hurt.

I need to be careful not to be misunderstood here. I am not referring, for example, to what the Nazis did and what the Allies did in World War II, and I am not saying that the Allies were like the Nazis. Many factors such as historical circumstances, reactivation of past victimizations, the leader's personality organization, existing military power and, most importantly, the degree of large-group regression can make a large-group dehumanize the "other" and be terribly cruel. In dealing with such an extremely regressed large group, the opposing group need not be identically as regressed as the perpetrating group.

When I speak of a similarity between enemies I am referring to certain large-group processes without considering the degree of their regression or its consequences. First, I am simply saying that when a large group's identity is threatened, the threatened large group automatically begins to hurt the aggressors' large-group identity, thus the attacked group begins to take on similarities to the perpetrator. Second, both groups utilize shared mental mechanisms such as introjection, projection, denial, dissociation, isolation, rationalization and intellectualization in their consciously or unconsciously motivated political propaganda. This comes from their leadership and/or is wished for and supported by the society. Third, humiliating, hurting and killing people in the name of large-group identity become acceptable by both sides.

If the leadership does not provide a kind of reality testing that includes an understanding of the enemy's (as large group) "psychic reality" and does not show some attempts to re- 
spond to it in humane ways, dangers become magnified and regression sets in or is maintained. Therefore, the idea of a large group becoming like its enemy is an area that needs to be studied openly again and again until new opportunities for different responses (above and beyond military ones) can be conceptualized. In fact, new strategies in international relations that don't include succumbing into large-group regression can be considered, and the so-called "diplomatic channels" need not be closed until a psychopolitical evaluation of the situation is completed.

\section{A “microscopic" examination of large-group psychology's negative influence: A story from Klooga}

There are many other concepts related to largegroup psychology that are not addressed in this chapter, but with the references to mourning and regression in large groups mentioned above, I tried to illustrate how large-group psychology in its own right needs to be studied. Now, by telling a story from the Estonian village of Klooga, I will illustrate, at a microscopic level, how shared group emotions and perceptions interfere with political/military/legal/ health issues, how we become similar to our enemy, and how we need to pay attention to large-group psychological problems, especially large-group identity issues, in order to find constructive solutions to our conflicts.

After Estonia gained its independence from the Soviet Union in 1991, there were major problems facing the newly independent country, one of them being the fact that one third of Estonia's one-and-a half million population is not ethnic Estonian, but Russian (or Russian speakers who were not ethnic Russians, but who were former Soviet citizens). In other words, when Estonia became independent, every third person was perceived as the "other," the "enemy." When Estonia was separated from the Soviet Union its people asked themselves, "Who are we now and what is our large-group identity now?" This concern with large-group identity necessarily brought about a societal regression that was exaggerated by the existence of huge numbers of "enemy" persons in Estonia who would, it was perceived, contaminate its large-group identity.

I went with an interdisciplinary team to Estonia in 1994 to carry out a diagnostic process and bring together selected individuals to participate in psychopolitical dialogues: high-level Estonians (such as parliamentarians, including the present-day president of Estonia, Arnold Rüütel), high-level representatives from Moscow (such as members of the Russian Duma) and leaders of the Russians (or Russian speakers) living in Estonia. We met over a period of several years, and afterwards we began to apply what we learned from these dialogue series to the population at large (for details see Volkan 16, 19). One place where we wanted to show that coexistence between ethnic Estonians and Russians living in Estonia was possible was a place called Klooga.

When I first went to Klooga in early 1996 it was virtually in ruins and had major public health hazards; it looked to me like a three-mile long and one-mile wide garbage dump. The town is only seven miles from Paldiski, the site of the former Soviet nuclear navy. Like Paldiski, Klooga had housed a Soviet military installation and had been off-limits to Estonians during the Soviet times, but after the withdrawal of the Soviet military some Estonians relocated in Klooga. At the time of my visit its population was about 2000 people, half Estonians and half Russians (including a few Russian-speakers).

The facilitating team's aim in Klooga was to develop some level of community cohesion without inter-ethnic conflict. With the help of our psychopolitical work, the Klooga residents developed a community center which became a place where everyone could come for learning (i.e., classes in computers, English, and Estonian) and for play. Children had a safe place to go after school. Teenagers gathered there too, and the center hosted holiday celebrations for the whole community. Along with the growing sense of community the center engendered, public health and other aspects of life in Klooga improved as well.

There were, of course, inevitable obstacles to our work in Klooga. The following example from our experience there, I believe, illustrates at a microscopic level how shared emotions and perceptions within a group may instigate unrealistic actions, and how members of the group may become "blind," unable to see the consequences of such actions.

The newly established, fledgling Estonian military, with its few colonels in charge, was using a field adjacent to Klooga for live target practice, a situation which greatly concerned Klooga's inhabitants, both Estonian and Russ- 
ian, because it posed a very real danger to the entire population, especially their children. A hidden script went something like this: We Estonians can now identify with our aggressors. Intellectually, we know that today Klooga is home to Estonian citizens and Estonian children too, but in our minds we continue to see this place as a Soviet military base. Thus, we bomb it repeatedly. The fledging Estonian military could have chosen any other place in Estonia for their target practice, but they insisted on "bombing" Klooga, the "Russian village," even though it was in reality no longer Russian.

The field where live ammunition fell was separated from the village by a 15 - to 20 -foot wide dirt road. The almost daily heavy artillery fire on the field neighboring Klooga was truly dangerous, and we were afraid that children playing nearby could be injured or killed. There was one incident when an Estonian villager tried to take a shortcut through the field with his old tractor and it was hit by artillery. Incredibly, the man survived. Initially the colonels would inform the village people when the "bombs" were to be dropped, but eventually they began to carry out their target practices without giving notice, which of course made the situation worse.

So, we had to devise a plan that would directly illustrate to Estonian authorities the danger that existed. On July 4, 1997 my team threw a big community-wide party in Klooga. We made no fuss about America and its independence, but everyone was told what the Fourth of July was all about (American Independence Day). We also invited several of the Estonian- and Russian-speaking participants from the original psychopolitical dialogue series, including some parliamentarians, to come with their families. Most of them lived in Tallinn, the capital city, and we were aware that they had never been to Klooga before. The Russian Embassy sent their second-ranking diplomat. The stage was set.

After the party, I invited our guests on a walk around the village, directing them to take the dirt road that separated the village from the field where the live artillery fell. I prayed that the "bombing" practice would resume so that our guests could experience what it was like to live in Klooga. Sure enough, the deafening explosions, "boom, boom," began. The target practice was impossible to ignore and provided unmistakable proof of what Klooga's inhabitants lived with every day. However, in spite of seeing the dangers of this practice for themselves and actually witnessing some Estonian kids playing nearby, our guests from the Parliament still could not bring themselves to do anything about the situation.

The next year I made more direct efforts to stop the "bombing" of Klooga, but there was still great resistance to our requests. Slowly we found ways to "educate" Klooga residents about the psychology of humiliation, the wish to reverse it, and the sometimes strange and dangerous efforts people employ to do so. We also discussed the concept of identification with the aggressor. Without our telling them to do so, Klooga residents (100 of them) wrote a letter to then-Estonian President Lennart Meri and asked that the shooting stop. Living in long-established democratic states we may think that this was a natural, in fact easy, thing to do. But living under communism and assimilating the rules and regulations of that political system, made this effort by the villagers a drastic one. It paid off when Klooga began to receive national attention. A television station sent its reporters and cameras to the village and there was a big fuss about the "bombing" of Klooga. The residents of Klooga had learned how to be assertive and use political and media pressure, and although the process took three years, the villagers succeeded in stopping the "bombing."

\section{Last remarks}

This chapter describes large-group identity and how a large group regresses when there is a threat to its identity. Large-group regression may result in destructive acts that kill many people and create serious public health problems. Psychoanalysts and other mental health workers who are willing to study large-group psychology in its own right and take part in interdisciplinary efforts have much to offer toward the understanding and management of deadly large-group conflicts. 


\section{References}

1. Freud S. Why war? Standard Edition 1932-1964 22:197-215.

2. Arlow J. Motivations for peace. In: Winnik, R Moses, M Ostow. Psychological Basis of War. Jerusalem: HZ/ Jerusalem Academic Press; 1973. p. 193-204

3. Volkan VD. The Intertwining of the Internal and External Wars. Paper presented at "Lost in Transmission" conference. Stockbridge, MA: The Erikson Institute, the Austen Riggs Center; 2004. (October 16).

4. Blum H. Superego formation, adolescent transformation and the adult neurosis. J Amer Psychoanal Assoc 1985; 4:887-909.

5. Jokl AM. Zwei Fällezum Thema "Bewältigung der Vergangenheit." (Two cases referring to the theme of "mastering the past.") Frankfurt A.M.: Jüdischer Verlag; 1997.

6. Grubrich-Simitis I. Extremtraumatisierung als kumulatives Trauma: Psychoanalytische Studien über seelische Nachwirkungen der Konzentrationslagerhaft bei Überlebenden und ihren Kindern (Extreme traumatization as a cumulative trauma: Psychoanalytic studies on the mental effects of imprisonment in concentration camps on survivors and their children). Psyche 1979; 33: 991-1023.

7. Ecstaedt I. Nationalismus in der "zweiten Generation:” Psychoanalyse von Hörigkeitsverhältnissen (National Socialism in the Second Generation: Psychoanalysis of Master-Slave Relationships). Frankfurt AM: Suhrkamp Verlag; 1989.

8. Streeck-Fischer A. Naziskins in Germany: How traumatization deals with the past. Mind and $\mathrm{Hu}-$ man Interaction 1999; 10:84-97.

9. Volkan VD, G Ast, W Greer. The Third Reich in the Unconscious: Transgenerational Transmission and its Consequences. New York: Brunner-Routledge; 2002.

10. Freud S. Totem and Taboo. Standard Edition 1913$1955 ; 13: 1-165$

11. Freud S. Group psychology and the analysis of the ego. Standard Edition 1921-1955; 18:65-143.

12. Freud $S$. The future of an illusion. Standard Edition 1921-1959; 21:5-56.

13. Freud S. Civilization and its discontents. Standard Edition 1930- 1959; 21:59-145.

14. Hendrick I. Facts and Theories of Psychoanalysis. New York: Knopf; 1958.

15. Volkan VD. The Need to Have Enemies and Allies: From Clinical Practice to International Relationships. Northvale, NJ: Jason Aronson; 1988.

16. Volkan VD. Bloodlines: From Ethnic Pride to Ethnic Terrorism. New York: Farrar-Straus and Giroux; 1997.
17. Volkan VD. Blind Trust: Large Groups and their Leaders in Times of Crises and Terror. Charlottesville, VA: Pitchstone Publishing; 2004.

18. Volkan VD. Politics and international relations. In: ES Person, AM Cooper, GO Gabbard. Textbook of Psychoanalysis. Washington: American Psychiatric Press; 2005. p. 523-33.

19. Volkan VD. Killing in the Name of Identity: A Study of Bloody Conflicts. Charlottesville, VA: Pitchstone Publishing; 2006.

20. Bion W. Experiences in Groups and Other Papers. New York: Basic Books; 1961.

21. Rice AK. Learning for Leadership: Interpersonal and Intergroup Relations. London: Tavistock Publications; 1965.

22. Turquet $P$. Threats to identity in the large group. In: L Kreeger. The Large Group: Dynamics and Therapy. London: Constable; 1975. p. 87-144.

23. Kernberg OF. Sanctioned political violence: A psychoanalytic view - Part1. Int J Psycho-Anal 2003; 84: 683-98.

24. Kernberg OF. Sanctioned political violence: A psychoanalytic view - Part 2. Int J Psycho-Anal 2003; 84: 683-98.

25. Volkan VD. Linking Objects and Linking Phenomena: A Study of the Forms, Symptoms, Metapsychology, and Therapy of Complicated Mourning. New York: International Universities Press; 1981.

26. Pollock GH. The Mourning-Liberation Process. vols 1 and 2. Madison, CT: International Universities Press; 1989.

27. Tähkä V. Dealing with object loss. Scandinavian Psychoanalytic Rev 1984; 7:13-33.

28. Freud S. Mourning and melancholia. Standard Edition 1917-1957; 14:258-77.

29. Volkan VD, N Itzkowitz. Turks and Greeks: Neighbors in Conflict. Cambridgeshire; England: Eothen Press; 1994.

30. Waelder R. The principle of multiple function: Observations on over-determination. Psychoal. Quart 1930-1936; 5:45-62.

31. Sebek M. The fate of the totalitarian object. Intel Forum Psychoanal 1996; 5:289-94.

32. Rangell L. The Mind of Watergate. New York: Norton; 1980.

33. Stern J. Deviance in the Nazi society. Mind and Human Interaction 2001; 12:218-37.

Article presented in 15/03/2006

Approved in 28/03/2006

Final version presented in 23/03/2006 